\title{
LEGAL PRINCIPLES OF THE UTILIZATION OF NATURAL RESOURCES
}

\author{
Nikmah Fitriah
}

Sultan Adam Colage Of Law

\begin{abstract}
This study aims to discover the principles of law in the use of natural resources. Pemanfaatan natural resources for the development and preservation of environmental functions must not be contradictory and mutual sacrifice, even the two should be mutually supportive and running parallel.

The research method used is Normative or Doctrinal Law research, namely research on Legal Principles, Concepts, and Implementation in society. The type of pure legal research is research based on the view that law is a positive norm in the national legal system of legislation. Oriented in a positivistic understanding with a doctrinal method, a statute approach, a conceptual approach.

The findings of this study are that the characteristics of laws and regulations that regulate the use of natural resources already contain the principles of sustainable development. Characteristics of statutory regulations governing the use of natural resources in the future in order to guarantee the value of certainty, the value of justice, and the value of the benefit in regulating the use of natural resources according to their function.
\end{abstract}

Keywords: Principles, Law, Utilization, Natural Resources 


\title{
ABSTRAK \\ PRINSIP HUKUM PEMANFAATAN SUMBER DAYA ALAM
}

\author{
Nikmah Fitriah \\ Sekolah Tinggi Ilmu Hukum Sultan Adam
}

\begin{abstract}
Penelitian ini bertujuan untuk menemukan prinsip hukum dalam pemanfaatan sumber daya alam. Pemanfaatan sumber daya alam untuk pembangunan dan pelestarian fungsi lingkungan hidup, tidak boleh bertentangan dan saling mengorbankan, bahkan keduanya harus saling mendukung dan berjalan sejajar.

Metode penelitian yang digunakan adalah penelitian Hukum Normatif atau Doktrinal, yakni penelitian terhadap Asas-asas Hukum, Konsep dan Implementasi di masyarakat. Tipe penelitian hukum murni, yakni penelitian dengan dasar pandangan bahwa hukum adalah norma-norma positif dalam sistem perundang-undangan hukum nasional. Dengan berorientasi pada pemahaman yang positivistik dengan metode doktrional melakukan pendekatan peraturan perundangan (statute approach), pendekatan konseptual (conceptual approach).

Temuan penelitian ini adalah Karakteristik peraturan perundang-undangan yang mengatur pemanfaataan sumber daya alam sudah mengandung prinsip pembangunan yang berkelanjutan. Karakteristik peraturan perundang-undangan yang mengatur pemanfaataan sumber daya alam yang akan datang agar menjamin nilai kepastian, nilaı keadilan dan nilai kemanfaatan dalam pengaturan pengaturan pemanfaataan sumber daya alam sesuai dengan fungsinya.
\end{abstract}

Kata Kunci : Prinsip, Hukum, Pemanfaatan, Sumber Daya Alam

\section{PENDAHULUAN \\ A. Latar Belakang}

Sumber daya alam di Indonesia merupakan anugrah Tuhan Yang Maha Esa yang harus selalu dijaga dan dimanfaatkan serta dilestarikan guna kesejahteraan bangsa Indonesia. Pengelolaan sumber daya alam di Indonesia mengacu pada ideologi penguasaan dan pemanfaatan sumber daya alam, sebagaimana tercermin secara konstitusional dalam Pasal 33 ayat (3) dan (4) Undang-Undang Dasar Negara Republik Indonesia Tahun 1945. (Selanjutnya disebut dengan UUD NRI 1945) Pasal 33 ayat (3) UUD NRI 1945 berbunyi "Bumi, air dan kekayaan alam yang terkandung didalamnya dikuasai oleh negara dan dipergunakan sebesar-besarnya untuk kemakmuran rakyat" dan Pasal 33 ayat (4) UUD NRI 1945 berbunyi "Perekonomian nasional diselenggarakan berdasar atas demokrasi ekonomi dengan prinsip kebersamaan, efisiensi berkeadilan, berkelanjutan, berwawasan lingkungan, kemandirian, serta dengan menjaga keseimbangan, kemajuan dan kesatuan ekonomi nasional." 
Ketentuan Pasal 33 ayat (3) dan (4) UUD NRI 1945 tersebut selanjutnya dijabarkan secara yuridis hierarkis ke dalam berbagai peraturan perundang-undangan terkait dengan pemanfaatan sumber daya alam, yang berada di bawah UUD NRI 1945. Hal ini mengandung makna bahwa pengaturan pemanfaatan sumber daya alam untuk menunjang pembangunan di seluruh wilayah Negara Indonesia harus berdasar atas demokrasi ekonomi dengan prinsip kebersamaan, efisiensi berkeadilan, berkelanjutan, berwawasan lingkungan, kemandirian, serta dengan menjaga keseimbangan kemajuan dan kesatuan ekonomi nasional.

Campur tangan Pemerintah tersebut diatas menunjukkan bahwa Indonesia menganut konsep Negara kesejahteraan (welfare state). Campur tangan Pemerintah tersebut diberi bentuk hukum agar segala sesuatunya tidak simpang siur serta memberikan kepastian hukum dan tidak menimbulkan keragu-raguan pada semua pihak yang bersangkutan dan bilamana menimbulkan konflik, penyelesaiannya lebih mudah.

Pemanfaatan sumber daya alam untuk pembangunan dan pelestarian fungsi lingkungan hidup, tidak boleh bertentangan dan saling mengorbankan, bahkan keduanya harus saling mendukung dan berjalan sejajar. Artinya perlu ditelaah lebih jauh, sampai dimanakah pelaksanaan pembangunan dengan memanfaatkan sumber daya alam tidak mengabaikan masalah pelestarian fungsi lingkungan hidup, sehingga pembangunan yang berwawasan lingkungan dapat diwujudkan dan lingkungan hidup yang terjaga kelestariannya akan dapat dimanfaatkan sampai generasi yang akan datang, atau biasa dikenal dengan istilah pembangunan yang berkelanjutan (sustainable development), yaitu memenuhi kebutuhan generasi sekarang tanpa mengurangi kemampuan generasi mendatang untuk memenuhi kebutuhannya. ${ }^{1}$ Pelaksanaan pembangunan berkelanjutan menurut A. Sonny Keraf ${ }^{2}$ harus memenuhi tiga prinsip yaitu prinsip demokrasi, prinsip keadilan dan prinsip berkelanjutan.

Peraturan perundang-undangan yang lahir yang pada hakikatnya bertujuan agar membentengi sumber daya alam di seluruh wilayah Indonesia tetap terjaga kelestariannya sehingga terjamin pembangunan yang berkelanjutan seperti yang diamanatkan oleh konstitusi sangatlah banyak. Misalnya Undang-Undang Nomor 5 Tahun 1990 tentang Konservasi Sumber Daya Alam Hayati dan Ekosistemnya, Undang-Undang Nomor 26 Tahun 2007 tentang Penataan Ruang, Undang-Undang Nomor 32 Tahun 2009 tentang Perlindungan dan Pengelolaan Lingkungan Hidup, Undang-Undang Nomor 41 Tahun 1999 tentang Kehutanan, Undang-Undang Nomor 4 Tahun 2009 tentang Pertambangan Mineral dan Batubara, Undang-Undang Nomor 18 Tahun 2013 tentang Pencegahan dan Pemberantasan Perusakan Hutan, Undang-Undang Nomor 32 Tahun 2014 tentang Konservasi Tanah dan Air. Setiap peraturan tersebut selalu mencantumkan kewajiban memelihara kelestarian fungsi lingkungan hidup dalam aktivitas pemanfaatan sumber daya alam, namun kenyataannya yang terjadi saat ini faktanya justru sebaliknya.

Lingkungan hidup Indonesia dari hari ke hari ada kecenderungan justru menurun tingkat kemampuannya untuk mendukung kehidupan yang kondusif, yaitu

${ }^{1}$ Koesnadi Hardjasoemantri, Hukum Tata Lingkungan, gadjah Mada University Press, Yogyakarta, 1994, hal. 22-23

${ }^{2}$ A.Sonny Keraf, Etika Lingkungan, Buku Kompas, Jakarta, 2006, hal. 168. 
ditandai dengan semakin banyaknya bencana alam yang kemungkinan disebabkan oleh ulah manusia yang melakukan aktivitas pemanfaatan sumber daya alam melebihi kemampuan dari alam tersebut untuk memberi manfaat buat kehidupan. Bencana alam seperti banjir, kabut asap, erosi, bukanlah bisa disebut takdir dari Tuhan, tapi lebih disebabkan oleh ulah manusia itu sendiri.

\section{B. Permasalahan}

Prinsip hukum dalam pemanfaatan sumber daya alam tinjauan terhadap peraturan perundang-undangan mengenai sumber daya alam.

\section{Metode}

Metode penelitian yang digunakan adalah Normatif dengan melakukan pendekatan peraturan perundangan (statute approach), pendekatan konseptual (conceptual approach).

\section{HASIL DAN PEMBAHASAN}

\section{A. Konsep Kekuasaan Negara Indonesia Atas Bumi, Air dan Kekayaan yang Terkandung Didalamnya}

Konsep kekuasaan negara Indonesia atas bumi, air dan kekayaan yang terkandung di dalamnya adalah Pasal 33 Ayat (3) UUD 1945 yang berbunyi "Bumi, air dan kekayaan alam yang terkandung didalamnya dikuasai oleh negara dan dipergunakan sebesar-besarnya untuk kemakmuran rakyat".

Berdasarkan kekuasaan negara atas bumi, air dan kekayaan yang terkandung di dalamnya mengandung makna bahwa di tangan negaralah kewenangan mengeluarkan segala bentuk perizinan. Akan tetapi bukan berarti kewenangan tersebut tidak memiliki batasan. Dalam Pasal 33 Ayat (4) UUD 1945 yang berbunyi "Perekonomian nasional diselenggarakan berdasar atas demokrasi ekonomi dengan prinsip kebersamaan, efisiensi berkeadilan, berkelanjutan, berwawasan lingkungan, kemandirian, serta dengan menjaga keseimbangan kemajuan dan kesatuan ekonomi nasional." Bunyi Pasal ini berisi prinsipprinsip hukum yang berlaku umum yang tentunya termasuk dalam aktivitas pertambangan, dimana salah satunya adalah prinsip pembangunan nasional harus diselenggarakan dengan prinsip berwawasan lingkungan. Jadi seharusnya negara tidak boleh hanya mengedepankan masalah kewenangan memberikan perizinan ada di tangan negara, sehingga bisa mengabaikan prinsip-prinsip hukum yang terkandung di dalam Pasal 33 Ayat (4) UUD 1945, khususnya yang berkaitan dengan prinsip hukum berwawasan lingkungan. 


\section{B. Konsep Lingkungan Hidup}

Lingkungan hidup menurut Munadjat Danusaputra " "Semua benda dan kondisi termasuk di dalamnya manusia dan tingkah perbuatannya yang terdapat dalam ruang dimana manusia berada dan mempengaruhi kelangsungan hudup serta kesejahteraan manusia dan jasad hidup lainya."

Secara garis besar menurut Fuad Amsyari ${ }^{4}$ lingkungan hidup dapat digolongkan atas 3 (tiga) golongan yaitu:

a. Lingkungan fisik

Lingkungan fisik adalah sesuatu di sekitar kita yang berbentuk benda mati seperti rumah, gunung, udara dan lain-lainnya.

b. Lingkungan biologis.

Lingkungan biologis adalah segala sesuatu yang berada di sekitar manusia yang berupa organisme hidup lainnya, selain dari manusia sendiri, binatang, tumbuh-tumbuhan dan lain-lain.

c. Lingkungan sosial.

Lingkungan sosial adalah manusia-manusia lain yang berada di sekitarnya seperti tetangga, teman dan lain-lain.

Uraian di atas memberikan gambaran bahwa manusia dalam hidupnya mempunyai hubungan secara bertimbal balik dengan lingkungannya. Manusia dalam hidupnya baik secara pribadi maupun sebagai kelompok masyarakat selalu berinteraksi dengan lingkungan dimana ia hidup, dalam artian menusia dengan berbagai aktivitasnya akan mempengaruhi lingkungannya dan perubahan lingkungan akan mempengaruhi kehidupan manusia.

Menurut Koesnadi Hardjasoemantri ${ }^{5}$ bahwa pelestarian itu berasal dari kata lestari yang mempunyai makna langgeng, tidak berubah. Apabila kata lestari ini dikaitkan dengan kata lingkungan, maka berarti bahwa lingkungan itu tidak boleh berubah, tetap dalam keadaan aslinya. Padahal pembangunan berarti perubahan. Membangun adalah merubah sesuatu, untuk mencapai taraf yang lebih baik. Dengan demikian maka yang dilestarikan bukanlah lingkungannya an sich, akan tetapi kemampuan lingkungan. Kemampuan lingkungan yang serasi dan seimbang inilah yang perlu dilestarikan, sehingga setiap perubahan yang diadakan dalam proses pembangunan, selalu diupayakan untuk meniadakan dan mengurangi dampak negatifnya agar keadaan lingkungan menjadi serasi dan seimbang pada tingkatan yang baru. Istilah pelestarian kemampuan lingkungan yang serasi dan seimbang membawa kepada keserasian antara pembangunan dan

${ }^{3}$ Abdurrahman, Pengantar Hukum Lingkungan Indonesia, P.T. Citra Aditya Bakti, Bandung, 1990, hal. 8

${ }^{4}$ Ibid, hal. 9

${ }^{5}$ Koesnadi Hardjasoemantri, Hukum Tata Lingkungan, Gadjah Mada University Press, Yogyakarta, 1994, hal. 115 
lingkungan., sehingga kedua pengertian itu yaitu pembangunan dan lingkungan tidak dipertentangkan satu dengan yang lainnya.

Untuk mencapai keserasian dan keseimbangan antara keseimbangan dan pengelolaan lingkungan hidup ini, Emil Salim ${ }^{6}$ mengemukakan satu konsep yang disebut eco development. Konsep ini tidak menolak diubah dan diolahnya sumber alam untuk pembangunan dan kesejahteraan asalkan pemanfaatan sumber alam tersebut dilakukan sebijaksana mungkin, sehingga dapat menopang pembangunan jangka panjang yang akan menuntun ke arah mutu hidup yang lebih tinggi dari generasi ke generasi. Dalam konsep ini berlaku dalil "apa yang diambil dari alam harus kembali kepada alam, sekurangkurangnya diganti dengan hal yang berperan serupa kepada alam”. Jadi pemanfaatan sumber alam, baik yang bisa diperbaharui seperti hutan, maupun yang tidak bisa diperbaharui seperti batubara, minyak bumi dan sebagainya, tidak boleh menghancurkan lingkungan hidup bagi peningkatan kesejahteraan generasi masa depan.

Ada tiga unsur yang mempengaruhi arah eco development menurut Emil Salim ${ }^{7}$ yaitu : "(1) Cara sumber dilakukan; (2) Cara teknologi dikembangkan; (3) Cara perbaikan mutu penduduk. Ketiga-tiganya memerlukan kebijaksanaan sumber alam, kebijaksanaan teknologi dan kebijaksanaan kependudukan.”

Selanjutnya menurut Emil Salim bahwa :

konsep dasar dalam kebijaksanaan sumber alam ialah agar penggunaan sumber alam sebijaksana mungkin. Sumber alam bukanlah variabel yang berdiri sendiri melainkan dipengaruhi oleh pola konsumsi, oleh permintaan, perilaku konsumen dan pada umumnya oleh gaya hidup yang dianut. Karenanya yang paling penting ialah gaya hidup itu harus diarahkan dengan mempertimbangkan kemampuan sumber alam yang diperlukan untuk mempertahankan suatu gaya hidup yang dianut itu. ${ }^{8}$

Kemudian kebijaksanaan teknologi dalam konsep eco development menurut Emil Salim bahwa Teknologi yang bersih yang berkemampuan melestarikan sumber alam yang dapat diperbaharui, dan kurang merusak sumber-sumber alam yang tidak dapat diperbaharui. Dan sasaran yang hendak dicapai dengan kebijaksanaan kependudukan adalah keseimbangan yang tepat antara jumlah serta pertambahan penduduk dan daya dukung sumber alam. Pengendalian jumlah penduduk melaui program Keluarga Berencana $(\mathrm{KB})$ dan sebaran penduduk yang merata dalam kaitannya dengan daya dukung sumber-sumber alam merupakan titik pusat kebijaksanaan kependudukan. ${ }^{9}$

${ }^{6}$ Emil Salim, Pembangunan Berwawasan Lingkungan, LP3ES. Jakarta, 1993, hal. 184-192.

\footnotetext{
${ }^{7}$ Ibid, hal. 192.

${ }^{8}$ Ibid.

${ }^{9}$ Ibid. hal.193
} 


\section{Konsep Pembangunan Berkelanjutan}

Cita-cita dan agenda pembangunan berkelanjutan tidak lain adalah upaya untuk mensinkronkan, mengintegrasikan, dan memberi bobot yang sama bagi tiga aspek utama pembangunan, yaitu aspek ekonomi, aspek sosial-budaya dan aspek lingkungan hidup. Gagasan ini adalah pembangunan ekonomi, sosial-budaya dan aspek lingkungan hidup harus dipandang sebagai terkait erat satu sama lain, sehingga unsur-unsur dari kesatuan yang saling terkait ini tidak boleh dipisahkan atau dipertentangkan satu dengan lainnya. Yang mau dicapai dengan pembangunan berkelanjutan adalah menggeser titik berat pembangunan dari hanya pembangunan ekonomi menjadi juga mencakup pembangunan sosial-budaya dan lingkungan hidup.

Menurut A. Sonny $\operatorname{Keraf}^{10}$, untuk mencapai ketiga aspek pembangunan berkelanjutan di atas, maka diperlukan tiga prinsip utama dalam pelaksanaannya, yaitu :

a. Prinsip demokrasi

Prinsip demokrasi sebagai prinsip moral yang paling mendasar adalah prinsip yang menjamin agar pembangunan dilaksanakan sebagai perwujudan kehendak bersama rakyat demi kepentingan bersama seluruh rakyat. Jadi pembangunan bukan dilaksanakan berdasarkan kehendak pemerintah atau partai politik demi kepentingan rezim atau partai yang sedang berkuasa.

Prinsip demokrasi mencakup aspek-aspek sebagai berikut :

1).Agenda utama pembangunan adalah agenda rakyat demi kepentingan rakyat. Jadi pemerintah harus menjamin bahwa agenda pembangunan yang dilaksanakannya memang benar-benar berasal dari rakyat dan untuk kepentingan bersama seluruh rakyat.

2).Adanya sebuah keharusan moral dan politik untuk keberadaan partisipasi masyarakat baik dalam merumuskan kebijakan pembangunan maupun dalam mengimplementasikaan kebijakan pembangunan.

3).Harus ada akses informasi yang jujur dan terbuka tentang agenda pembangunan dan proses perumusan agenda pembangunan.

4).Ada akuntabilitas publik tentang agenda pembangunan, proses perumusan kebijakan pembangunan dan implementasi pembangunan. Karena dengan agenda pembangunan yang berasal dari rakyat dan demi kepentingan rakyat banyak, maka harus ada pertanggungjawaban publik tentang sejauh mana aspirasi rakyat telah didengar, diakomodasi, dan diwujudkan serta sejauh mana tujuan pembangunan yaitu kepentingan bersama seluruh rakyat telah benar-benar diwujudkan dengan komitmen dan upaya yang serius pada semua pihak.

\footnotetext{
${ }^{10}$ A.Sonny Keraf, Op.Cit, hal. 175-182
} 
b. Prinsip keadilan

Prinsip ini pada dasarnya mau menjamin bahwa semua orang dan kelompok masyarakat memperoleh peluang yang sama untuk ikut dalam proses pembangunan dan kegiatan-kegiatan produktif serta ikut dalam menikmati hasil-hasil pembangun.

Prinsip keadilan menuntut:

1).Adanya perlakuan yang sama bagi semua orang dan kelompok masyarakat, dalam proses pembangunan, khususnya dalam berpartisipasi melaksanakan dan menikmati hasil pembangunan dan mempunyai akses terhadap peluang dan sumber-sumber ekonomi, termasuk sumber daya alam.

2).Agar ada distribusi manfaat dan beban secara proposional antara semua orang dan kelompok masyarakat.

3).Agar ada peluang yang sama bagi generasi yang akan datang untuk memperoleh manfaat secara sama atau proporsional dari sumber daya ekonomi yang ada.

4).Agar kerugian akibat proses pembangunan yang dialami oleh kelompok masyarakat tertentu harus bisa ditebus atau dikonpensasi secara seimbang atau proporsional baik oleh negara ataupun oleh kelompok yang menimbulkan kerugian tersebut.

c. Prinsip berkelanjutan

Prinsip ini mengharuskan adanya rancangan agenda pembangunan dalam dimensi visioner jangka panjang, untuk melihat dampak pembangunan baik positif maupun negatif dalam segala aspeknya tidak hanya dalam dimensi jangka pendek.

Prinsip berkelanjutan mengharuskan:

1).Untuk memilih alternatif pembangunan yang lebih hemat sumber daya dan mampu mensinkronkan aspek konservasi dengan aspek pemanfaatan secara arif.

2).Untuk menggunakan pola-pola pembangunan dan konsumsi yang hemat energi, hemat bahan baku, dan hemat sumber daya alam lainnya.

3).Menerapkan prinsip produksi bersih dengan melakukan seleksi yang ketat terhadap produksi, teknologi, bahan baku, dan manajemen yang meminimalisasi limbah dalam setiap kegiatan pembangunan dan kegiatan produksi ekonomi.

4).Untuk sebisa mungkin menggunakan kembali bahan dan teknologi yang telah dipakai, mengurangi bahan baku, dan mendaur ulang sisa-sisa proses produksi yang ada.

Prinsip keberlanjutan pada akhirnya sangat menunjang prinsip keadilan antargenerasi, karena pada dasarnya prinsip keadilan dan prinsip keberlanjutan menuntut semua pihak untuk bersikap hati-hati dan arif dalam setiap kebijaksanaan pembangun agar manfaat jangka pendek yang diperoleh dari kegiatan pembangunan tidak sampai menimbulkan dan dibayar mahal dengan kerugian jangka panjang yang tidak sebanding dengan manfaat jangka pendek tersebut. Kerugian jangka panjang itu tidak semata-mata 
bersifat ekonomis-material-fisik, tetapi juga bersifat non-material, mental, spiritual, kesehatan, sosial-budaya dan nilai serta mutu kehidupan manusia.

D. Masalah Keberadaan Prinsip Pembangunan Yang Berkelanjutan dalam Peraturan Perundang-Undangan Yang Mengatur Pemanfaataan Sumber Daya Alam

\section{Undang-Undang Nomor 5 Tahun 1960 tentang Peraturan DasarPokok- pokok Agraria}

Undang-Undang Nomor 5 Tahun 1960 tentang Peraturan Dasar Pokokpokok Agraria (Lembaran Negara Tahun 1960 Nomor 104), (selanjutnya disebut UUPA), secara umum tidak ada aturan yang mengatur secara khusus tentang pembagian fungsi kawasan sebagai kawasan budi daya dan kawasan lindung, namun dengan memperhatikan oreintasi UUPA yang beroreintasi kepada konservasi sumber daya alam, khususnya tanah, maka otomatis bisa dikatakan bahwa UUPA termasuk peraturan perundang-undangan yang menjadikan prinsip kelestarian fungsi lingkungan hidup sebagai prinsip dalam pengaturan pemanfaatan dan pengelolaan tanah. Dengan tegas dinyatakan dalam Pasal 15 UUPA, bahwa dengan memperhatikan pihak ekonomi lemah, maka setiap orang, badan hukum atau instansi yang mempunyai hubungan hukum dengan tanah wajib memelihara tanah, termasuk menambah kesuburannya serta mencegah kerusakannya. UUPA bahkan mengancam pelanggar ketentuan itu dengan pidana atau hukuman kurungan selama-lamanya 3 bulan dan/atau denda setinggi-tingginya Rp. 10.000,- (Pasal 52 ayat (1) UUPA).

Orientasi konservasi dari UUPA juga dapat dilihat pada Pasal 2 ayat (2) huruf a, yaitu bahwa amanah untuk memelihara bumi, air, ruang angkasa dan kekayaan alam yang terkandung didalamnya tidak hanya dibebankan kepada setiap orang yang mempunyai hubungan hukum dengannya tetapi juga merupakan tanggung jawab dan wewenang negara. Bunyi Pasal ini menunjukkan adanya kewajiban dari negara untuk menjaga kelestarian fungsi lingkungan hidup. Jadi tentunya keberadaan UU No. 19/2004 yang justru melegalkan aktivitas tambang terbuka di dalam kawasan hutan lindung, yang sudah pasti akan merusak fungsi hutan untuk memberikan perlindungan pada kawasan di sekitar hutan dari bencana alam, karena aktivitas tambang terbuka akan mengakibatkan hilangnya kawasan hutan, sangat bertentangan dengan UUPA. Padahal UUPA seharusnya dijadikan sebagai undang-undang payung dari peraturan-peraturan lain yang mengatur mengenai agraria dan pertanahan termasuk peraturan perundang-undangan bidang kehutanan. Tapi kenyataannya justru sebaliknya, terdapat beberapa ketentuan dari berberapa undang-undang sektoral yang tidak sesuai dengan apa yang telah digariskan di dalam UUPA.

\section{Undang-Undang Nomor 5 Tahun 1990 tentang Konservasi Sumber Daya Alam Hayati dan Ekosistemnya}

Undang-Undang Nomor 5 Tahun 1990 tentang Konservasi Sumber Daya Alam Hayati dan Ekosistemnya (Lembaran Negara Tahun 1990 Nomor 49, Tambahan Lembaran Negara Nomor 3419), ini lahir pada tanggal 10 Agustus 1990, setelah ada kesadaran perlunya melindungi ekosistem dan perlindungan jenis tumbuhan dan satwa yang berguna bagi pelestarian alam. Kesadaran tersebut setelah 23 (dua puluh tiga) tahun lahirnya Undang-Undang Nomor 5 Tahun 1967. 
Undang-Undang Nomor 5 Tahun 1990 tentang Konservasi Sumber Daya Alam Hayati dan Ekosistemnya secara keseluruhan beroreintasi pada konservasi, bukan kepada produksi. Misalnya dalam bagian konsederans "Menimbang" huruf a Undang-Undang Nomor 5 Tahun 1990 tentang Konservasi Sumber Daya Alam Hayati dan Ekosistemnya menyatakan, bahwa sumber daya alam hayati Indonesia dan ekosistemnya perlu dikelola dan dimanfaatkan secara lestari, selaras, serasi dan seimbang bagi kesejahteraan masyarakat Indonesia pada khususnya dan umat manusia pada umumnya, baik untuk masa kini maupun masa depan. Oleh karena itu dalam Pasal 2 Undang-Undang Nomor 5 Tahun 1990 tentang Konservasi Sumber Daya Alam Hayati dan Ekosistemnya memuat "asas" konservasi sumber daya alam hayati dan ekosistemnya secara serasi dan seimbang. Hal ini dikuatkan lagi dalam Pasal 3 Undang-Undang Nomor 5 Tahun 1990 tentang Konservasi Sumber Daya Alam Hayati dan Ekosistemnya yang menyatakan tujuan konservasi sumber daya alam hayati dan ekosistemnya adalah untuk mengusahakan terwujudnya kelestarian sumber daya alam hayati serta keseimbangan ekosistemnya sehingga dapat mendukung upaya peningkatan kesejahteraan masyarakat dan mutu kehidupan manusia.

Perlindungan kawasan pada hakikatnya adalah melindungi kawasan beserta unsur kehidupan diatasnya sebagai wilayah perlindungan dan pelestarian sistem penyangga kehidupan agar tetap utuh. Sehingga kegiatan yang ada di dalam kawasan hanya diperbolehkan untuk kegiatan tertentu yaitu antara lain penelitian dan pengembangan yang menunjang fungsi kawasan, pendidikan, menunjang budidaya, budaya dan wisata alam (kecuali di cagar alam tidak diperkenankan kegiatan wisata alam). Sedangkan kegiatan lain di luar hal-hal tersebut diatas dilarang termasuk kegiatan pertambangan. Keutuhan ekosistem merupakan hal yang sangat penting dalam pengelolaan kawasan hutan konservasi.

Dalam Penjelasan Undang-Undang Nomor 5 Tahun 1990 tentang Konservasi Sumber Daya Alam Hayati dan Ekosistemnya dijelaskan bahwa berhasilnya konservasi sumber daya alam hayati dan ekosistemnya berkaitan erat dengan tercapainya tiga sasaran konservasi, yaitu: (1). menjamin terpeliharanya proses ekologis yang menunjang sistem penyangga kehidupan bagi kelangsungan pembangunan dan kesejahteraan manusia (perlindungan sistem penyangga kehidupan); (2). menjamin terpeliharanya keanekaragaman sumber genetik dan tipetipe ekosistemnya sehingga mampu menunjang pembangunan, ilmu pengetahuan, dan teknologi yang memungkinkan pemenuhan kebutuhan manusia yang menggunakan sumber daya alam hayati bagi kesejahteraan (pengawetan sumber plasma nutfah); (3). mengendalikan cara-cara pemanfaatan sumber daya alam hayati sehingga terjamin kelestariannya.

Akibat sampingan penerapan ilmu pengetahuan dan teknologi yang kurang bijaksana, belum harmonisnya penggunaan dan peruntukan tanah serta belum berhasilnya sasaran konservasi secara optimal, baik di darat maupun di perairan dapat mengakibatkan timbulnya gejala erosi genetik, polusi, dan penurunan potensi sumber daya alam hayati (pemanfaatan secara lestari). 


\section{Undang-Undang Nomor 32 Tahun 2009 tentang Pengelolaan dan Perlindungan Lingkungan Hidup}

Dengan lahirnya Undang-Undang Nomor 32 Tahun 2009 tentang Pengelolaan dan Perlindungan Lingkungan Hidup (Lembaran Negara Republik Indonesia Tahun 2009 Nomor 140, Tambahan Lembaran Negara Republik Indonesia Nomor 5059) ini, pemerintah pusat dan daerah berkewajiban membuat kajian lingkungan hidup strategis. Kajian itu untuk memastikan pembangunan berkelanjutan telah menjadi dasar dan terintegrasi dalam kebijakan, rencana, dan program pembangunan. Pemanfaatan sumberdaya alam juga harus didasarkan pada rencana perlindungan dan pengelolaan lingkungan hidup (PPLH) yang menjadi dasar penyusunan rencana pembangunan jangka panjang dan menengah.

Penguatan AMDAL (analisa mengenai dampak lingkungan) untuk mencegah kerusakan lingkungan dengan meningkatkan akuntabilitas, penerapan sertifikasi kompetensi penyusun dokumen AMDAL, penerapan sanksi hukum bagi pelanggar bidang AMDAL dan AMDAL sebagai persyaratan utama dalam memperoleh izin lingkungan. Perizinan diperkuat dengan menjadikan izin lingkungan sebagai prasyarat memperoleh izin usaha/kegiatan dan izin usaha/kegiatan dapat dibatalkan apabila izin lingkungan dicabut. Sistem hukum diperkuat dengan memperluas kewenangan PPNS. Dalam hal penegakan hukum lingkungan PPNS berwewenang menghentikan pelanggaran seketika di lapangan. Penyidik PNS dapat melakukan penangkapan dan penahanan serta hasil penyidikan disampaikan ke jaksa penuntut umum yang berkoordinasi dengan kepolisian.

\section{Undang-Undang Nomor 26 Tahun 2007 tentang Penataan Ruang}

Dalam penjelasan umum UUPR Angka 5 Undang-Undang Nomor 24 Tahun 1992 tentang Penataan Ruang sebagaimana telah diubah dengan UndangUndang Nomor 26 Tahun 2007 disebutkan bahwa "penataan ruang sebagai suatu sistem perencanaan tata ruang, pemanfaatan ruang, dan pengendalian pemanfaatan ruang merupakan satu kesatuan yang tidak terpisahkan antara yang satu dan yang lain dan harus dilakukan sesuai dengan kaidah penataan ruang sehingga diharapkan : (1). Dapat mewujudkan pemanfaatan ruang yang berhasil guna dan berdaya guna serta mampu mendukung pengelolaan lingkungan hidup yang berkelanjutan. (2). Tidak terjadi pemborosan pemanfaatan ruang. (3). Tidak menyebabkan terjadinya penurunan kualitas ruang." Penataan ruang yang didasarkan pada karakteristik, daya dukung dan daya tampung lingkungan, serta didukung oleh teknologi yang sesuai akan meningkatkan keserasian, keselarasan dan keseimbangan subsistem. Hal tersebut berarti akan dapat meningkatkan kualitas ruang yang ada.

Selanjutnya dalam Pasal 5 ayat (2) UUPR mengatur bahwa "penataan ruang berdasarkan fungsi utama kawasan, terdiri dari kawasan lindung dan kawasan budidaya. Kemudian Pasal 1 angka (21) UUPR dijelaskan bahwa kawasan lindung adalah wilayah yang ditetapkan dengan fungsi utama melindungi kelestarian fungsi lingkungan hidup yang mencakup sumber daya alam dan sumber daya buatan. Kawasan yang termasuk dalam kategori kawasan lindung adalah :

1).kawasan yang memberikan perlindungan kawasan bawahannya yang mencakup kawasan hutan lindung, kawasan bergambut, kawasan resapan air; 
2).kawasan perlindungan setempat yang mencakup sempadan pantai, sempadan sungai, kawasan sekitar danau/waduk, kawasan sekitar mata air,

3).kawasan terbuka hijau termasuk di dalamnya hutan kota;

4).kawasan suaka alam yang mencakup kawasan cagar alam, suaka margasatwa;

5).kawasan pelestarian alam yang mencakup taman nasional, taman hutan raya, taman wisata alam;

6).kawasan cagar budaya;

7).kawasan rawan bencana alam yang mencakup antara lain kawasan rawan letusan gunung api, gempa bumi, tanah longsor, serta gelombang pasang dan banjir;

8).kawasan lindung lainnya mencakup taman buru, terumbu karang, kawasan perlindungan plasma nuftah, kawasan pengungsian satwa dan kawasan pantai berhutan bakau.

Dalam Pasal 1 angka 22 UUPR dijelaskan bahwa kawasan budidaya adalah wilayah yang ditetapkan dengan fungsi utama untuk dibudidayakan atas dasar kondisi dan potensi sumber daya alam, sumber daya manusia dan sumber daya buatan. Kawasan budidaya meliputi :

1)kawasan hutan produksi yang mencakup kawasan hutan produksi terbatas, kawasan hutan produksi tetap, kawasan hutan yang dapat dikonversi;

2) kawasan hutan rakyat;

3) kawasan pertanian yang mencakup kawasan pertanian lahan basah, kawasan pertanian lahan kering, kawasan tanaman tahunan/perkebunan, kawasan peternakan, kawasan perikanan;

4) kawasan pertambangan yang mencakup golongan bahan galian strategis, golongan bahan galian vital atau golongan bahan galian yang tidak termasuk kedua golongan tersebut;

5) kawasan peruntukan industri;

6) kawasan pariwisata; dan

7) kawasan permukiman.

\section{Undang-Undang Nomor 4 Tahun 2009 tentang Pertambangan Mineral dan Batubara}

Undang-Undang Nomor 4 Tahun 2009 tentang Pertambangan Mineral dan Batubara adalah pengganti dari Undang-Undang Nomor 11 Tahun 1967 tentang Ketentuan-ketentuan Pokok Pertambangan. Undang-undang ini berorientasi pada eksploitasi sumber daya alam dan bisa dikatakan pro pada kapital. Sedangkan 
Undang-Undang Nomor 4 Tahun 2009 berorientasi terhadap peningkatan produksi dan konservasi sumber daya mineral dan batubara.

Menurut Maria S.W. Sumardjono, dkk, isyarat bahwa UU No. 4/2009 berorientasi pada peningkatan produksi yang merupakan upaya untuk menghasilkan sebanyak mungkin mineral dan batubara dapat dilihat dari beberapa aspek, yaitu Pertama, penempatan mineral dan batubara sebagai salah satu komponen penggerak pertumbuhan ekonomi. Hal ini dinyatakan dalam bagian "Menimbang huruf b UU No. 4/2009" yang menjadi landasan filosofisnya yang berbunyi :"mineral dan batubara merupakan sumber daya untuk berkontribusi pada pertumbuhan ekonomi nasional dan pembangunan daerah secara berkelanjutan". Kedua, Pasal 18 UU No. 4/2009 diantaranya menentukan tentang optimalisasi hasil sumber daya mineral dan batubara yang dapat dihasilkan. Ini mengandung makna bahwa jumlah produk yang dihasilkan harus optimal, yaitu setinggi mungkin untuk berkontribusi pada pertumbuhan ekonomi.

Orientasi UU No. 4/2009 selain pada peningkatan produksi juga beroreintasi pada konservasi. Menurut Maria S.W. Sumardjono, dkk konservasi bermakna adanya keberlanjutan eksistensi sumber daya mineral dan batubaranya sendiri dan pemanfaatannya. Keberlanjutan sumber daya mineral dan batubara bermakna bahwa ketersediaannya tetap terjamin dengan cara tidak mengeksploitasinya secara berlebihan. Upaya untuk menjaga keberlanjutannya dilakukan diantaranya adalah : Pertama, adanya asas keseimbangan, berkelanjutan dan berwawasan lingkungan dalam pengelolaan sumber daya mineral dan batubara seperti tercantum dalam Pasal 2 UU No. 4/2009. Kedua salah satu tujuan pengelolaan mineral dan batubara adalah menjamin manfaat pertambangan secara berkelanjutan dan berwawasan lingkungan hidup sebagaimana ditentukan dalam Pasal 3 UU No. 4/2009.

Pertambangan adalah sebagian atau seluruh tahapan kegiatan dalam rangka penelitian, pengelolaan dan pengusahaan mineral atau batubara yang meliputi penyelidikan umum, eksplorasi, studi kelayakan, penambangan pengelolaan dan pemurnian, pengangkutan dan penjualan serta kegiatan pasca tambang. Kegiatan fisik untuk melakukan kegiatan pertambangan dalam kawasan hutan harus terlebih dahulu mendapat izin pinjam pakai dari Departemen Kehutanan, ketentuan di bidang kehutanan membatasi kegiatan pertambangan tersebut. Kawasan hutan suaka alam tidak dibenarkan sama sekali untuk kegiatan penambangan, yang dibolehkan adalah pada kawasan hutan produksi terbatas, sedangkan pada kawasan hutan lindung hanya boleh dilakukan dengan persyaratan tertentu, penambangannya tidak boleh tambang terbuka.

\section{Undang-Undang Nomor 18 Tahun 2013 tentang Pencegahan dan Pemberantasan Perusakan Hutan}

Dalam bagian Penjelasan Undang-Undang Nomor 18 Tahun 2013 tentang Pencegahan dan Pemberantasan Perusakan Hutan (Lembaran Negara Republik Indonesia Tahun 2013 Nomor 130) dijelaskan bahwa hutan Indonesia sebagai karunia dan anugerah Tuhan Yang Maha Esa yang diamanatkan kepada bangsa Indonesia merupakan unsur utama sistem penyangga kehidupan manusia dan merupakan modal 
dasar pembangunan nasional yang memiliki manfaat nyata, baik manfaat ekologi, sosial budaya, maupun ekonomi agar kehidupan dan penghidupan bangsa Indonesia berkembang secara seimbang dan dinamis.

Hutan Indonesia merupakan salah satu hutan tropis terluas di dunia sehingga keberadaanya menjadi tumpuan keberlangsungan kehidupan bangsa-bangsa di dunia, khususnya dalam mengurangi dampak perubahan iklim global. Oleh karena itu, pemanfaataan dan penggunaannya harus dilakukan secara terencana, rasional, optimal, dan bertanggung jawab sesuai dengan kemampuan daya dukung serta memperhatikan kelestarian fungsi dan keseimbangan lingkungan hidup guna mendukung pengelolaan hutan dan pembangunan kehutanan yang berkelanjutan bagi kemakmuran rakyat.

Pembangunan hutan berkelanjutan memerlukan upaya yang sungguhsungguh karena masih terjadi berbagai tindak kejahatan kehutanan, seperti pembalakan liar, penambangan tanpa izin, dan perkebunan tanpa izin. Kejahatan itu telah menimbulkan kerugian negara dan kerusakan kehidupan sosial budaya dan lingkungan hidup yang sangat besar serta telah meningkatkan pemanasan global yang telah menjadi isu nasional, regional, dan internasional. Akhir-akhir ini perusakan hutan semakin meluas dan kompleks. Perusakan itu terjadi tidak hanya di hutan produksi, tetapi juga telah merambah ke hutan lindung ataupun hutan konservasi.

Perusakan hutan telah berkembang menjadi suatu tindak pidana kejahatan yang berdampak luar biasa dan terorganisasi serta melibatkan banyak pihak, baik nasional maupun internasional. Kerusakan yang ditimbulkan telah mencapai tingkat yang sangat mengkhawatirkan bagi kelangsungan hidup bangsa dan negara. Oleh karena itu, penanganan perusakan hutan harus dilakukan secara luar biasa. Upaya menangani perusakan hutan sesungguhnya telah lama dilakukan, tetapi belum berjalan secara efektif dan belum menunjukkan hasil yang optimal. Hal itu antara lain disebabkan oleh peraturan perundang-undangan yang ada belum secara tegas mengatur tindak pidana perusakan hutan yang dilakukan secara terorganisasi. Oleh karena itu, diperlukan payung hukum dalam bentuk undang-undang agar perusakan hutan terorganisasi dapat ditangani secara efektif dan efisien serta pemberian efek jera kepada pelakunya.

Berdasarkan pemikiran sebagaimana diuraikan di atas, upaya pemberantasan perusakan hutan melalui Undang-Undang Nomor 18 Tahun 2013 tentang Pencegahan dan Pemberantasan Perusakan Hutan ini dilaksanakan dengan mengedepankan asas keadilan dan kepastian hukum, keberlanjutan, tanggung jawab negara, partisipasi masyarakat, tanggung gugat, prioritas, serta keterpaduan dan koordinasi.

Selanjutnya, pembentukan Undang-Undang Nomor 18 Tahun 2013 tentang Pencegahan dan Pemberantasan Perusakan Hutan ini, selain memiliki aspek represif juga mempertimbangkan aspek restoratif, bertujuan untuk: (a). memberikan payung hukum yang lebih tegas dan lengkap bagi aparat penegak hukum untuk melakukan pemberantasan perusakan hutan sehingga mampu memberi efek jera bagi pelakunya; (b). meningkatkan kemampuan dan koordinasi aparat penegak hukum dan pihak-pihak terkait melalui lembaga pencegahan dan pemberantasan perusakan hutan dalam upaya pemberantasan perusakan hutan. (c). meningkatkan peran masyarakat 
dalam menjaga kelestarian hutan terutama sebagai bentuk kontrol sosial pelaksanaan pemberantasan perusakan hutan; (d). mengembangkan kerja sama internasional dalam rangka pemberantasan perusakan hutan secara bilateral, regional, ataupun multilateral; dan (e). menjamin keberadaan hutan secara berkelanjutan dengan tetap menjaga kelestarian dan tidak merusak lingkungan serta ekosistem sekitarnya guna mewujudkan masyarakat sejahtera.

\section{Undang-Undang Nomor 32 Tahun 2014 tentang Konservasi Tanah dan Air}

Undang-Undang Nomor 32 Tahun 2014 tentang Konservasi Tanah dan Air (Lembaran Negara Republik Indonesia Tahun 2014 Nomor 299), (selanjutnya disebut UU No. 32/2014), diundangkan di Jakarta tanggal 17 Oktober 2014. UndangUndang ini dipandang perlu karena pengaturan mengenai konservasi tanah dan air saat ini dianggap masih belum memadai dan belum diatur secara terpadu dan komprehensif.

Selanjutnya dalam bagian pertimbangan keluarnya UU No. 32/2014 dikatakan bahwa tanah dan air dalam wilayah Negara Kesatuan Republik Indonesia merupakan karunia sekaligus amanah Tuhan Yang Maha Esa untuk bangsa Indonesia yang perlu dijaga kelestariannya dan dimanfaatkan untuk sebesar-besarnya untuk kemakmuran rakyat, baik bagi generasi sekarang maupun bagi generasi yang akan datang. Kemudian dikatakan juga bahwa tanah dan air merupakan sumber daya alam yang tak terbarukan dan mudah terdegradasi fungsinya karena posisi geografis dan akibat penggunaan yang tidak sesuai dengan fungsi, peruntukan dan kemampuannya sehingga perlu dilindungi, diputihkan, ditingkatkan, dan dipelihara melalui Konservasi Tanah dan Air.

Penyelenggaraan Konservasi Tanah dan Air menurut Pasal 2 UU No. 32/2014 berdasarkan pada asas partisipatif, keterpaduan, keseimbangan, keadilan, kemanfaatan, kearifan lokal dan kelestarian. Dalam penjelasan Pasal 2 UU No. 32/2014 dijelaskan maksud dari asas "kelestarian" adalah bahwa setiap orang memikul kewajiban dan tanggung jawab terhadap generasi mendatang dan terhadap sesamanya, dalam satu generasi dengan melakukan upaya pelestarian daya dukung ekosistem dan memperbaiki kualitas tanah dan air.

Dalam Pasal 1 UU No. 32/2014 terdapat pembedaan fungsi antara kawasan yang ditetapkan menjadi kawasan lindung dan kawasan budi daya. Menurut UU No. 32/2014 yang dimaksud dengan kawasan lindung adalah wilayah yang ditetapkan dengan fungsi utama melindungi kelestarian lingkungan hidup yang mencakup sumber daya alam dan sumberdaya buatan, dan yang dimaksud dengan kawasan budi daya adalah wilayah yang ditetapkan dengan fungsi utama untuk dibudidayakan atas dasar kondisi dan potensi sumber daya alam, sumber daya manusia, dan sumber daya buatan. 


\section{E. Karakteristik peraturan perundang-undangan yang akan datang dalam pengaturan pemanfaataan sumber daya alam yang menjamin terwujudnya prinsip pembangunan yang berkelanjutan}

\section{Nilai Keadilan dalam Pengaturan Pengaturan Pemanfaataan Sumber Daya Alam sesuai dengan Fungsinya}

Diskusi mengenai hubungan kebebasan dan hukum menyiratkan pentingnya keadilan. Otonomi atau kebebasan seorang individu harus tidak melanggar hak orang lain atas kebebasan. Oleh karena itu, dalam masyarakat bebas, hukum berfungsi menjamin tegaknya keadilan. Menurut teori Etis, hukum semata-mata bertujuan keadilan. Isi hukum di tentukan oleh keyakinan mengenai yang etis tentang yang adil dan tidak. Dengan kata lain, hukum menurut teori ini bertujuan merealisir atau mewujudkan keadilan.

Hukum harus bisa menjadi instrumen untuk mencapai keadilan. Pertama, setiap hukum harus adil, sehingga aplikasinya oleh pengadilan tidak memihak. Kedua, hukum harus bisa memastikan bahwa negara akan memperlakukan setiap warganya secara adil, dan bahwa setiap warga negara melakukan keadilan terhadap sesamanya. Keadilan menjadi keadilan karena dalam interaksi sosial hak orang lain dihargai; sebaliknya, ketidakadilan terjadi karena dalam interaksi sosial hak orang lain dilanggar atau dilecehkan.

Secara teoretis dapat dikemukakan beberapa asas untuk menentukan suatu itu adil atau tidak adil, yaitu: (1) Asas persamaan, di mana diadakan pembagian secara mutlak. Setiap warga masyarakat mendapatkan bagian secara merata tanpa memperhatikan kelebihan/kekurangan individu; (2) Asas kebutuhan, di mana setiap warga masyarakat mendapatkan bagian sesuai dengan keperluannya yang nyata; (3) Asas kualifikasi, di mana keadilan didasarkan pada kenyataan, bahwa yang bersangkutan akan dapat mengerjakan tugas yang diberikannya kepadanya; (4) Asas prestasi objektif, bahwa bagian seseorang warga masyarakat didasarkan pada syarat-syarat objektif; (5) Asas subjektif, yang didasarkan pada syarat-syarat subjektif, misalnya: intensi, ketekunan, kerajinan, dan lain-lain.

Walaupun hukum dikatakan bertujuan mewujudkan keadilan, faktanya hukum tidak identik dengan keadilan. Ini berarti terdapat peraturan perundang-undangan yang hanya mengakomodasi kepentingan pemerintah sebagai "agen pembangunan" untuk menetapkan kebijakan pengelolahan sumber daya alam secara sentralistik. Misalnya Peraturan perundang-undangan yang mengatur tentang pemanfaatan kawasan hutan lindung dalam UU No. 41/1999 jo UU No. 19/2004 tentang aktivitas tambang terbuka di hutan lindung bersifat diskriminatif dan jauh dari rasa keadilan seperti dijelaskan pada pembahasan terdahulu.

Sebagai konsekuensi produk perundang-undangan yang sentralistik tersebut adalah menguatnya pemerintah dan swasta dalam kontrol atas sumber daya hutan, sehingga menampakkan sebuah potret yang memposisikan sumber daya alam sebagai objek yang hanya mempunyai kewajiban untuk memenuhi kehendak dan keinginan pemerintah dan pengusaha, tanpa punya hak untuk dilestarikan. Hal ini tentunya sangat bertolak belakang dengan teori lingkungan hidup yang menempatkan ruang sebagai salah satu dari unsur lingkungan hidup, satu kesatuan dengan unsur yang lainnya termasuk 
manusia, dalam posisi yang sejajar, sama-sama memiliki hak dan kewajiban dalam mendukung berlangsungnya kehidupan di muka bumi ini.

Dalam membangun hukum sumber daya alam ke depan, perlu dilakukan perubahan dalam cara pandang tentang pola pemanfaatan ruang yang ada di wilayah negara Indonesia pada umumnya dan pola pemanfaatan sumber daya alam pada khususnya, yang lebih berwawasan lingkungan. Konsep pemanfaatan sumber daya alam yang memiliki nilai keadilan dilihat dari konsep ekologi adalah sebuah konsep pengaturan pemanfaatan sumber daya alam yang tidak menempatkan ruang sebagai obyek saja tapi juga sebagai subjek, sama dengan manusia yang pada hakikatnya juga adalah salah satu komponen unsur lingkungan hidup. Peraturan tentang pemanfaatan sumber daya alam, haruslah mempunyai substansi yang memberikan kepastian hukum untuk sumber daya alam bisa berfungsi sesuai dengan peruntukannya.

Berwawasan jangka panjang berarti pula bahwa perencanaan, pengelolaan, dan pengusahaan sumber daya alam ke depan, harus berangkat dari kepentingan antargenerasi, yaitu selain kepentingan generasi sekarang, juga harus memperhatikan kepentingan generasi yang akan datang, sebagai bagian dari fungsi negara dalam melindungi kepentingan keadilan antar generasi. Prinsip-prinsip keadilan antar generasi meletakkan tiga kewajiban mendasar lagi generasi sekarang dalam konservasi sumber daya alam, yaitu: (1) Conservation of option, menjaga generasi mendatang dapat memilih kuantitas keanekaragaman sumber daya alam; (2) Conservation of quality, menjaga lingkungan agar lestari;(3) Conservation of acces, menjamin generasi mendatang minimal memiliki akses yang sama dengan generasi sekarang atas titipan kekayaan alam ciptaan Tuhan Yang Maha Esa.

\section{Nilai Kemanfaatan dalam Pengaturan Pengaturan Pemanfaataan Sumber Daya Alam sesuai dengan Fungsinya}

Penganut aliran Utilistis menganggap bahwa tujuan dari hukum semata-mata adalah memberikan kemanfaatan atau kebahagiaan yang sebesar-besarnya bagi sebanyak-banyaknya kepada warga masyarakat. Pandangannya didasarkan pada falsafah bahwa setiap warga negara masyarakat mencari kebahagiaan, dan hukum merupakan salah satu alatnya. Pakar aliran utilistis diantaranya adalah Jeremy Bentham. Ia tidak puas dengan Undang-Undang Dasar Inggris serta mendesak agar diadakan perubahan dan perbaikan berdasarkan suatu ide yang revolusioner. Ide utilistis ini diperoleh Bentham dari Helvetius dan Beccaria, dan mengemukakan ajarannya dalam karangannya yang berjudul Introduction to morals and legislation. Bentham berpendapat bahwa adanya negara dan hukum semata-mata hanya demi manfaat sejati, yaitu kebahagian mayoritas rakyat.

Menurut Bentham hakikat kebahagiaan adalah kenikmatan dan kehidupan yang bebas dari kesengsaraan. Karenanya, maksud manusia melakukan tindakan adalah untuk mendapatkan kebahagiaan yang sebesar-besarnya dan mengurangi penderitaan. Baik buruknya tindakan diukur dari baik buruknya akibat yang dihasilkan tindakan itu. Suatu tindakan dinilai baik jika tindakan itu menghasilkan kebaikan. Sebaliknya, dinilai buruk jika mengakibatkan keburukan (kerugian). Oleh Bentham, teori utilistis itu secara analogis diterapkannya pada bidang hukum. Maka menurut Bentham, baik buruknya hukum harus diukur dari baik buruknya akibat yang dihasilkan oleh penerapan hukum itu. Suatu ketentuan hukum baru dapat dinilai baik jika akibat yang dihasilkan dari 
penerapannya adalah kebaikan, kebahagian sebesar-besarnya, serta berkurangnya penderitaan dan sebaliknya, dinilai buruk jika penerapannya menghasilkan akibat yang tidak adil, kerugian, dan hanya memperbesar penderitaan. Bagi pengembangan ilmu hukum, teori analogi ini akan sangat bermanfaat bagi kegiatan evaluasi hukum, yaitu untuk mengukur kualitas dari peraturan perundang-undangan.

Dalam menjalankan pengelolaan dan pemanfaatan yang hanya mengedepankan aspek ekonomi dan mengabaikan aspek ekologi, sudah seharusnya ditinggalkan. Sudah seharusnya dikembangkan suatu model pengelolaan dan pemanfaatan sumber daya alam yang baik dan benar. Misalnya di bidang pertambangan, sudah seharusnya membangun peradapan yaitu kegiatan usaha pertambangan yang memenuhi ketentuan-ketentuan, kriteria, kaidah-kaidah, dan norma-norma yang tepat sehingga pemanfaatan sumber daya mineral memberikan hasil yang optimal dan dampak buruk untuk lingkungan yang minimal. Lebih lanjut, good mining practice meliputi, aspek perizinan, teknis penambangan, Keselamatan Dan Kesehatan Kerja (K3), lingkungan, keterkaitan hulu-hilir/konservasi/nilai tambah dan pengembangan masyarakat/wilayah di sekitar lokasi kegiatan, dan mempersiapkan penutupan pasca tambang, dalam bingkai kaidah peraturan perundangan dan standar yang berlaku sesuai tahap-tahap kegiatan pertambangan.

Keharusan memasukkan kaidah teknik pertambangan yang baik terutama kalau aktivitas pertambangan tersebut dilakukan di kawasan hutan lindung, sebagai kawasan yang juga berfungsi sebagai kawasan perlindungan untuk kawasan di sekitarnya, merupakan suatu keharusan sehingga merupakan landasan hukum yang kuat bagi pemerintah dalam melakukan pengawasan dan pengendalian kegiatan usaha pertambangan yang berada di wilayah hukum Indonesia. Konsep prinsip-prinsip pengelolaan dan pengusahaan bahan galian atau usaha pertambangan yang baik dan benar bukan hanya dalam rangka menjawab tudingan miring selama ini, tetapi mempunyai dimensi yang lebih luas lagi, yaitu bahwa prinsip-prinsip pertambangan yang baik dan benar selain memecahkan persoalan seperti dijelaskan diatas, juga harus memuat semangat, maksud, dan tujuan untuk : (1) mengendalikan distribusi pemanfaatan bahan galian, dengan prioritas utama dan pertama dan/atau terlebih dahulu diperuntukkan bagi kepentingan bangsa dan negara; (2) meningkatkan mining recovery atau perolehan bahan galian semaksimal mungkin; (3) meningkatkan efisiensi pemakaian bahan galian, sebagai upaya penghematan pemakaian bahan dasar industri berdimensi jangka panjang, hal ini berkaitan dengan keberadaan bahan galian sebagai bahan yang tidak dapat terbarukan "non-renewable resources". Artinya, penghematan juga berkaitan dengan kepentingan generasi yang akan datang; (4) meningkatkan perolehan devisa negara dari sektor pertambangan, karena dengan adanya mining recovery, berarti pula meningkatkan pula jumlah perolehan bahan galian dan memperpanjang umur tambang.

Menurut Nandang Sudrajat, pengelolaan dan pengusahaan pertambangan yang baik dan benar, termasuk pertambangan yang dilakukan di kawasan hutan lindung adalah suatu proses kegiatan usaha pertambangan mulai dari penetapan wilayah, sampai dengan proses pengolahan dan pemurnian dilaksanakan dengan cara yang sistematis, memenuhi kriteria teknis, menghormati norma-norma, hak-hak dasar masyarakat setempat, dan keseimbangan lingkungan hidup, sesuai dengan peraturan perundangundangan, untuk dipergunakan sebesar-besarnya bagi kemakmuran rakyat dan kemandirian bangs 


\section{KESIMPULAN}

Karakteristik peraturan perundang-undangan yang mengatur pemanfaataan sumber daya alam sudah mengandung prinsip pembangunan yang berkelanjutan. Karakteristik peraturan perundang-undangan yang mengatur pemanfaataan sumber daya alam yang akan datang agar menjamin nilai kepastian, nilai keadilan dannilar kemanfaatandalam pengaturan pengaturan pemanfaataan sumber daya alam sesuai dengan fungsinya.

\section{DAFTAR PUSTAKA}

Abdurrahman, 1990, Pengantar Hukum Lingkungan Indonesia, P.T. Citra Aditya Bakti, Bandung.

..............., 1992, Ketentuan-ketentuan Pokok Tentang Masalah Agraria, Kehutanan, Pertambangan, Transmigrasi, dan LingkunganHidup, Alumni, Bandung.

Abu Daud Busroh, A. Abubakar Busro. 1984. Hukum Tata Negara. Ghalia Indonesia. Jakarta

Achmad Ali, 1996, Menguak Tabir Hukum, Chandra Pratama, Jakarta. 1998, Menjelajahi Kajian Empiris Terhadap Hukum, Yarsif, Jakarta

Bambang Songgono, 1998, Metodologi Penelitian Hukum, PT. Raja Grafindo Persada, Jakarta.

Emil Salim, 1993, Pembangunan Berwawasan Lingkungan, LP3ES. Jakarta.

C.S.T. Kansil, Christine S.T. Kansil, 2002, Hukum Tata Negara Republik Indonesia 2, Rineka Cipta, Jakarta

Jakarta

1997, Hukum Tata Negara Republik Indonesia 1, Rineka Cipta, 2008, Hukum Tata Negara Republik Indonesia 2, Rineka Cipta, Jakarta

Harun M. Husein, 1995, Lingkungan Hidup (Masalah, Pengelolaan dan Penegakan Hukumnya, Bumi Aksara, Jakarta.

Koesnadi Hardjasoemantri, 1994, Hukum Tata Lingkungan, Gadjah Mada University Press, Yogyakarta 
Bambang Songgono, 1998, Metodologi Penelitian Hukum, PT. Raja Grafindo Persada, Jakarta.

Emil Salim, 1993, Pembangunan Berwawasan Lingkungan, LP3ES. Jakarta.

Harun M. Husein, 1995, Lingkungan Hidup (Masalah, Pengelolaan dan Penegakan Hukumnya, Bumi Aksara, Jakarta.

Marhaeni Ria Siombo, 2012, Hukum Lingkungan dan Pelaksanaan Pembangunan Berkelanjutan di Indonesia, Gramedia Pustaka Umum, Jakarta.

Moh. Mahfud MD. 1998. Politik Hukum di Indonesia. Pustaka LP3ES Indonesia. Yogyakarta

--------------------, 2010, Perdebatan Hukum Tata Negara Pasca Amandemen konstitusi, Rajagrafindo Persada, Jakarta

--------------------, 2010, Membangun Politik Hukum, Menegakkan Konstitusi, Rajagrafindo Persada, Jakarta

Moh. Kusnardi, Harmaily Ibrahim. 1988. Pengantar Hukum Tata Negara Indonesia. CV. Sinar Bakti. Jakarta

Morissan, 2005, Hukum Tata Negara RI Era Reformasi, Ramdina Prakarsa, Jakarta

Ni'matul Huda, 2011, Hukum Tata Negara Indonesia, PT Raja Grafindo Persada, Jakarta

Peter Mahmud Marzuki, 2008, Pengantar Ilmu Hukum, Kencana Prenada Media Group, Jakarta

2011, Penelitian Hukum, Kencana Prenada Media Group, Jakarta

P Sudharto Hadi, 2000, Manusia dan Lingkungan, Badan Penerbit Universitas Diponegoro, Semarang.

Soehino, 1981, Hukum Tata Negara, Liberty, Yogyakarta.

Sukandarrumi di. 1999. Bahan Galian Industri. Gadjah Mada University Press. Yogyakarta.

Taufiqurohman Syahuri, 2011, Tafsir Konstitusi Berbagai Aspek Hukum, Kharisma Putra Utama, Jakarta 